\title{
AKTIVITAS INSEKTISIDA BINTARO (Cerbera odollam Gaertn) TERHADAP HAMA Eurema SPp. PADA SKALA LABORATORIUM
}

\author{
Activities of Bintaro (Cerbera odollam Gaertn.) Insecticide on Eurema spp. \\ Pest in Laboratory Scale
}

Sri Utami

Balai Penelitian Kehutanan Palembang

J1. Kol. Burlian KM 6,5 Puntikayu Po. Box 179, Palembang

Telp./Fax. (0711) 414864 Email : uut_balittaman@yahoo.com

Naskah masuk : 6 Mei 2010; Naskah diterima : 28 September 2010

\begin{abstract}
One of some problems in sengon plantation is pests infestation. Eurema spp. is one of important pests which attact sengon plants in nursery and field. There are some techniques to control Eurema spp. A contro using biopesticides is one of some techniques to control some pests. This research aimed to study effect of bintaro's extract to control Eurema spp. in laboratory. The results showed that bintaro extracts have significantly effect to pest mortality and insect development. Insecticidal effects of Bintaro seeds extract is more strong than fruits and leaves extract. Bintaro seeds extract affected Eurema spp. mortality procentage is 90\%, and successful making of pupa and imago are 16,67\% and need 1,7 long days than control treatment. Chemical compound in bintaro extract is the most likely cause insectisidal effect to Eurema spp.
\end{abstract}

Keywords: bintaro, biopesticide, Eurema spp., mortality, sengon

\begin{abstract}
ABSTRAK
Salah satu permasalahan yang dihadapi dalam budidaya sengon (Paraserianthes falcataria) adalah serangan hama. Eurema spp. merupakan salah satu hama utama yang menyerang tanaman sengon baik pada skala persemaian maupun lapangan. Terdapat banyak teknik pengendalian yang bisa dilakukan untuk mengendalikan hama Eurema spp. Salah satunya yaitu pengendalian dengan memanfaatkan tanaman yang berpotensi sebagai insektisida nabati. Tujuan penelitian ini adalah mengkaji pengaruh ekstrak bintaro dalam mengendalikan serangga hama Eurema spp. pada skala laboratorium. Hasil penelitian menunjukkan bahwa ekstrak bintaro memberikan pengaruh signifikan terhadap mortalitas dan penghambatan perkembangan serangga hama Eurema spp. Ekstrak biji bintaro mempunyai efek insektisidal paling kuat dibandingkan dengan ekstrak daging buah dan daun bintaro. Ekstrak biji bintaro menyebabkan mortalitas larva Eurema spp. sebesar 90\%, keberhasilan pembentukan pupa dan imago masing-masing sebesar $16,67 \%$ dengan waktu yang dibutuhkan 1,7 hari lebih lama dibandingkan dengan kontrol. Diduga kandungan kimia yang terdapat di dalam ekstrak bintaro mampu memberikan efek insektisidal terhadap hama Eurema spp.
\end{abstract}

Kata kunci : bintaro, Eurema spp., insektisida nabati, mortalitas, sengon

\section{PENDAHULUAN}

\section{A. Latar Belakang}

Eurema spp. merupakan hama utama pada tanaman sengon (Paraserianthes falcataria). Selain tanaman sengon, Eurema spp. juga menyerang tanaman dadap (Erythrina sp.), jengkol (Pithecelobium jiringa), johar (Cassia siamea), jayanti (Sesbania sesban), dan turi (Sesbania grandiflora). Pada tanaman sengon, Eurema spp. merupakan hama utama yang menyerang tanaman, baik tingkat semai maupun tanaman di lapangan. Serangan pada tingkat semai dapat menimbulkan kematian bibit, karena daun tanaman sengon habis dimakan (Suharti, 1991). Serangga hama ini mempunyai daerah 
penyebaran yang sangat luas, mulai dari Afrika, Tiongkok, Jepang, Korea, Asia Tenggara, Australia, sampai ke pulau-pulau Pasifik.

Selama ini masyarakat mengendalikan serangan Eurema spp. dengan menggunakan insektisida kimia. Penggunaan insektisida kimia yang berlebihan dan tidak bijak akan menimbulkan dampak negatif, diantaranya terjadi resistensi hama, resurgensi hama, ledakan hama sekunder, dan tidak ramah lingkungan. Oleh karena itu pemanfaatan tumbuhan sebagai pengendali hama merupakan alternatif pengendalian hama yang bijak dan senantiasa memperhatikan aspek ekologi.

Bintaro (Cerbera odollam Gaertn) merupakan salah satu jenis tanaman famili Apocynaceae. Tanaman ini merupakan jenis tanaman penaung yang biasa ditanam di pekarangan rumah, taman-taman, dan banyak ditemukan di pinggiran jalan tol. Heyne (1987) melaporkan bahwa biji bintaro sangat berbahaya bagi hewan dan manusia. Orang-orang Melayu menganggap biji bintaro sebagai racun yang dapat mematikan, sedangkan masyarakat di Maluku menganggap bahwa biji bintaro dapat menyebabkan sesak nafas yang berat. Selain itu Tarmadi et al. (2007) melaporkan bahwa ekstrak kulit dan daun bintaro mempunyai efek mortalitas terhadap rayap (Captotermes sp.).

Pemanfaatan tanaman bintaro untuk pengendalian hama hutan seperti Eurema spp. merupakan aspek penting dalam rangka menunjang keberhasilan pembangunan hutan tanaman. Oleh karena itu efektivitas dan efisiensi serta potensi pemanfaatan dan pengembangan tanaman bintaro sebagai alternatif pengendali hama Eurema spp. perlu diteliti.

\section{B. Tujuan Penelitian}

Penelitian ini bertujuan untuk mengkaji pengaruh ekstrak bintaro terhadap efek mortalitas dan perkembangan serangga hama Eurema spp. pada skala laboratorium.

\section{BAHAN DAN METODE}

\section{A. Tempat dan Waktu}

Penelitian dilakukan di Laboratorium Perlindungan Hutan, Pusat Penelitian dan Pengembangan Hutan Tanaman, Bogor, dari bulan Agustus hingga September 2009.

\section{B. Metode Penelitian}

\section{Eksplorasi Hama Eurema spp.}

Serangga hama Eurema spp. diperoleh dari hutan sengon rakyat di sekitar Palasari, Bogor. Serangga yang digunakan adalah larva instar 2. Larva yang diperoleh dari lapangan, langsung digunakan sebagai serangga uji, tidak dilakukan rearing/perbanyakan di laboratorium mengingat persentase keberhasilan rearing larva Eurema spp. sangat kecil.

\section{Eksplorasi Tanaman Bintaro}

Bagian tanaman bintaro yang digunakan sebagai bahan ekstrak yaitu biji, daging buah, dan daun bintaro, yang didapatkan di sekitar halaman kampus IPB Darmaga.

\section{Ekstraksi}

Bagian tanaman bintaro yang diambil dari lapangan kemudian dipotong-potong dan dikeringanginkan selama seminggu. Bagian dari tanaman yang telah dikeringanginkan digiling hingga halus, kemudian direndam. Bagian dari tanaman uji direndam dalam pelarut metanol dengan perbandingan $1: 3(\mathrm{w} / \mathrm{v})$ selama $24 \mathrm{jam}$. Setelah 24 jam rendaman disaring dengan corong Buchner yang dialasi kertas saring. Selanjutnya pelarut metanol diuapkan dengan menggunakan rotary evaporator sampai dihasilkan ekstrak kasar. Ekstrak kasar bisa disimpan di lemari es sampai saat digunakan. Ekstrak kasar ini digunakan untuk pengujian.

\section{Uji Efikasi Ekstrak Bintaro terhadap Larva Eurema spp.}

Konsentrasi yang digunakan yaitu $0,125 \%, 0,25 \%, 0,5 \%, 1 \%$ dan kontrol dengan pelarut metanol ditambah pengemulsi (Latron 77 $0,1 \%$ ) dengan perbandingan $1: 1$. Setiap konsentrasi diuji sebanyak 3 ulangan dengan 10 ekor larva untuk setiap ulangannya. Metode yang digunakan yaitu metode residu pada daun.

Daun sengon yang digunakan sebagai pakan uji sebanyak 2 helai daun per ulangan. Permukaan daun pakan diolesi larutan ekstrak sebanyak $50 \mu \mathrm{l}$ dengan microsyringe. Setelah pelarutnya menguap, daun pakan diletakkan dalam cawan petri berdiameter $9 \mathrm{~cm}$ yang telah dialasi tisu. Pada setiap cawan petri diletakkan 10 ekor larva uji. Larva kontrol diberi pakan daun yang hanya diolesi metanol. Pemberian pakan 
daun perlakuan dilakukan selama 48 jam, kemudian larva diberi pakan daun segar tanpa perlakuan.

Pengamatan dilakukan sampai larva mencapai instar akhir dengan mengamati kematian larva. Pengamatan persen kematian dilakukan selama 7 hari setelah perlakuan (HSP). Data kematian dihitung dalam persen kematian dengan rumus sebagai berikut :

$$
\text { Persen kematian }(\%)=\frac{\sum \text { larva yang mati }}{\sum \text { total larva }} \times 100 \%
$$

Menurut Prijono (1998), aktivitas insektisida ekstrak diklasifikasikan dalam beberapa kategori yaitu : 1) aktivitas kuat : mortalitas $(\mathrm{m}) \geq 95 \%, 2)$ agak kuat : $75 \% \leq \mathrm{m}<$ $95 \%, 3$ ) cukup kuat : $60 \% \leq \mathrm{m}<75 \%, 4)$ sedang : $40 \% \leq \mathrm{m}<60 \%, 5$ ) agak lemah : $25 \% \leq \mathrm{m}<40 \%$, 6) lemah : $5 \% \leq \mathrm{m}<25 \%$, 7) tidak aktif: $\mathrm{m}<5 \%$.

Larva yang masih hidup terus diamati perkembangannya sampai menjadi pupa dan imago. Persentase keberhasilan pembentukan pupa dihitung dengan menggunakan rumus sebagai berikut:

Persen pembentukan pupa $(\%)=\sum$ pupa yang terbentuk x 100\% $\sum$ larva yang hidup

Persentase keberhasilan pembentukan imago dihitung dengan menggunakan rumus sebagai berikut:

Persen pembentukan imago $=\sum$ imago yang terbentuk $\mathrm{x} 100 \%$ $\overline{\sum \text { pupa yang terbentuk }}$

\section{Analisis Data}

Data hubungan antara mortalitas larva dengan konsentrasi ekstrak diolah dengan analisis probit menggunakan program Polo Plus untuk memperoleh nilai Lethal Concentration (LC). Sedangkan data perkembangan larva sampai menjadi imago diolah dengan sidik ragam ANOVA dan nilai tengah diuji Duncan dengan program SAS versi 6.1.

\section{HASIL DAN PEMBAHASAN}

\section{A. Hasil Penelitian}

\section{Pengaruh Ekstrak Bintaro terhadap Mortalitas Larva Eurema spp.}

Beberapa ekstrak bintaro memberikan pengaruh yang signifikan terhadap mortalitas larva seperti yang tersaji pada Tabel 1. Larva yang mengalami kematian, tubuhnya kaku, lunak, dan lama kelamaan mengecil. Pada larva yang mati tidak tampak adanya gejala gangguan yang berkaitan dengan sistem hormon perkembangan serangga karena tidak terjadi bentuk yang menyimpang. Kematian larva pada perlakuan ekstrak biji diawali dengan paralisis (tungkai sudah tidak mampu lagi menopang tubuh), hal ini diduga karena biji bintaro banyak mengandung minyak sehingga minyak tersebut menempel pada tubuh larva dan mengakibatkan spirakel larva tersumbat. Dari tiga jenis ekstrak bintaro, ekstrak biji yang memberikan pengaruh paling kuat terhadap mortalitas larva. Semua kontrol pada setiap perlakuan tidak mengakibatkan kematian larva. Ekstrak biji, daging buah, dan daun bintaro memberikan efek insektisidal bersifat agak lemah hingga agak kuat dimana besarnya mortalitas larva berturut-turut $36,67 \%$ - 90\%; $33,33 \%$ - 83,33\%; dan 36,67\% - 80\%. Pada konsentrasi terendah, ekstrak biji dan daun menyebabkan mortalitas larva sebesar 36,67\% tetapi pada konsentrasi tertinggi, ekstrak biji lebih kuat dalam menyebabkan kematian larva dengan persentase mortalitas sebesar $90 \%$. Disamping jenis ekstrak, konsentrasi ekstrak juga memberikan pengaruh yang signifikan terhadap mortalitas larva. Semakin tinggi konsentrasi maka akan semakin tinggi pula persentase mortalitas larva Eurema spp.

Kematian larva diamati selama 7 HSP. Pada hari pertama sudah terjadi kematian tetapi persentase mortalitasnya sangat rendah seperti yang terlihat pada Gambar 1, 2, dan 3 pada perlakuan tiga jenis ekstrak. Pada grafik tersebut menggambarkan mortalitas larva setiap hari pengamatan selama tujuh hari. Pada 1 HSP, persentase mortalitas pada tiga jenis ekstrak masih kecil berkisar antara 13,33\% $20 \%$. Secara umum ketiga jenis ekstrak menunjukkan bahwa pada hari kedua setelah perlakuan, mortalitas larva paling besar. Kemudian pada pengamatan selanjutnya terjadi penurunan mortalitas larva. Mulai hari keenam sudah tidak terjadi kematian larva kecuali pada konsentrasi 1\% pada semua jenis ekstrak. Pada pengamatan hari ketujuh sudah tidak lagi terjadi kematian larva. Hal ini menunjukkan bahwa ekstrak bintaro mampu bekerja mulai 1 HSP dan paling efektif pada hari kedua pada semua jenis ekstrak bintaro. 
Tabel(Table) 1. Pengaruh ekstrak bintaro terhadap mortalitas larva Eurema spp. (Effect of bintaro extracts to mortality on Eurema spp. larvae)

\begin{tabular}{|c|c|c|c|}
\hline \multirow{2}{*}{$\begin{array}{c}\text { Konsentrasi/ } \\
\text { Concentration } \\
(\%)\end{array}$} & \multicolumn{3}{|c|}{ Mortalitas Larva/Larvae Mortality (\%) } \\
\hline & $\begin{array}{l}\text { Biji bintaro } \\
\text { /Bintaro seed }\end{array}$ & $\begin{array}{c}\text { Daging buah } \\
\text { bintaro/Bintaro fruits }\end{array}$ & $\begin{array}{c}\text { Daun bintaro / Bintaro } \\
\text { leaves }\end{array}$ \\
\hline $\begin{array}{l}\text { Kontrol } \\
0,125 \\
0,25 \\
0,5 \\
1 \\
\end{array}$ & $\begin{array}{l}0,00 \mathrm{a} \\
36,67 \mathrm{~b} \\
56,67 \mathrm{c} \\
83,33 \text { d } \\
90,00 \quad \mathrm{~d}\end{array}$ & $\begin{array}{l}0,00 \mathrm{a} \\
33,33 \mathrm{~b} \\
36,67 \mathrm{~b} \\
56,67 \mathrm{c} \\
83,33 \text { d }\end{array}$ & $\begin{array}{l}0,00 \mathrm{a} \\
36,67 \mathrm{~b} \\
43,33 \mathrm{bc} \\
53,33 \quad \mathrm{c} \\
80,00 \quad \mathrm{~d}\end{array}$ \\
\hline
\end{tabular}

${ }^{a}$ Mortalitas pada 7 HSP. Rataan pada kolom yang sama yang diikuti oleh huruf yang sama tidak berbeda nyata berdasarkan uji selang berganda Duncan pada taraf nyata 5\% (The larvae mortality was observed for seven days after treatment. The average in the same column followed by the same letters is not significant based on Duncan's Multiple Range Test, $\alpha=5 \%$ )

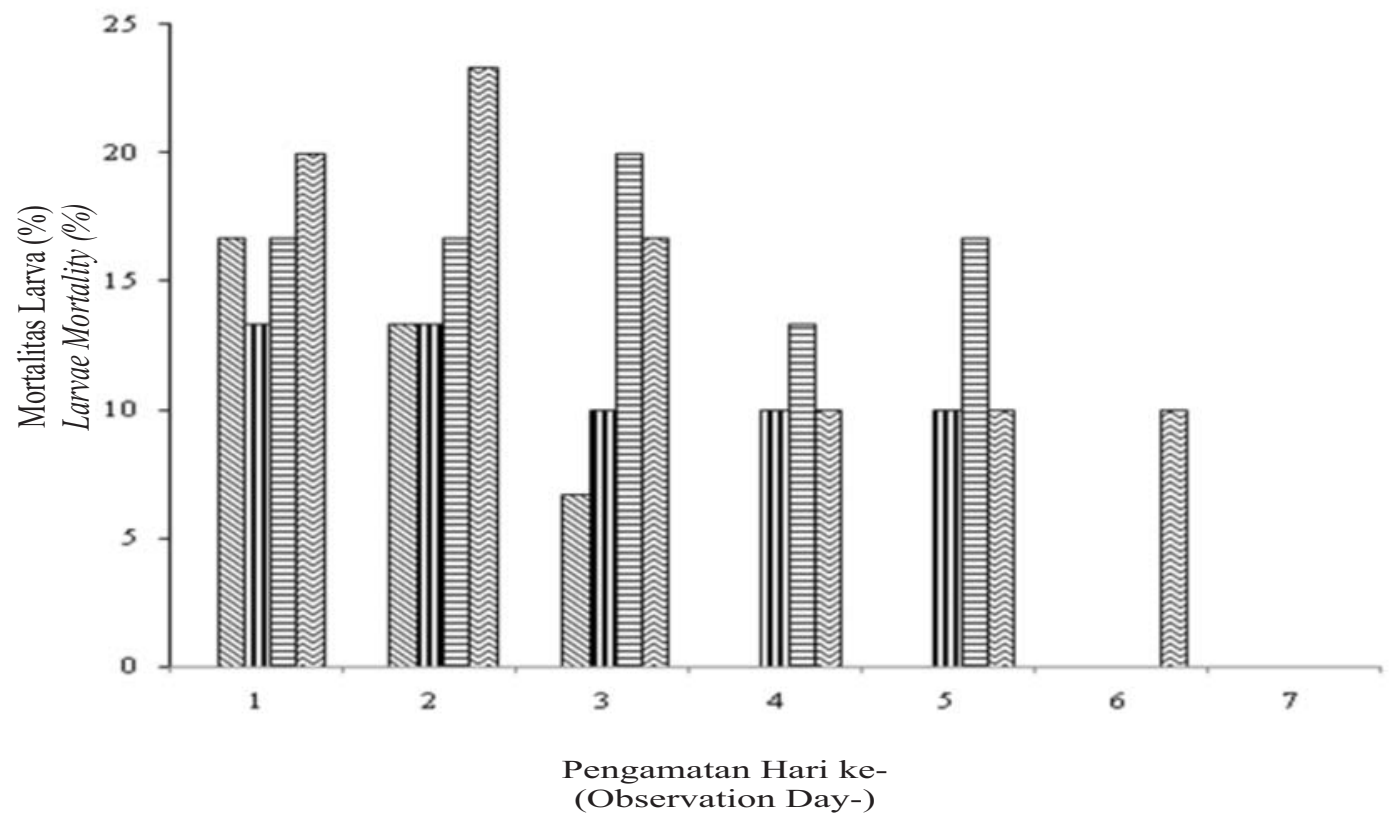

Gambar (Figure)1. Mortalitas Eurema spp. selama tujuh hari pengamatan pada perlakuan ekstrak biji bintaro(Euremaspp.mortalityduringforsevendaysobservationonextractstreatment of bintaro'sseed)

Hasil analisis probit dengan menggunakan program Polo Plus menunjukkan bahwa pada konsentrasi kurang dari 0,5\% semua jenis ekstrak diharapkan dapat memberikan persentase mortalitas sampai $50 \%$ dan pada konsentrasi kurang dari 2\% ekstrak biji diharapkan dapat menyebabkan mortalitas larva hingga 95\% (Tabel 2). Berdasarkan nilai $\mathrm{Lc}_{50}$, ekstrak biji bintaro 1,7 dan 1,6 kali lebih toksik dibandingkan ekstrak daging buah dan daun bintaro. Sedangkan berdasarkan nilai $\mathrm{LC}_{95}$, ekstrak biji bintaro 2,8 dan 4,7 kali lebih toksik dibandingkan dengan ekstrak daging buah dan daun bintaro. Hal ini menunjukkan bahwa ekstrak biji bintaro lebih toksik dibandingkan dengan dua jenis ekstrak lainnya. 


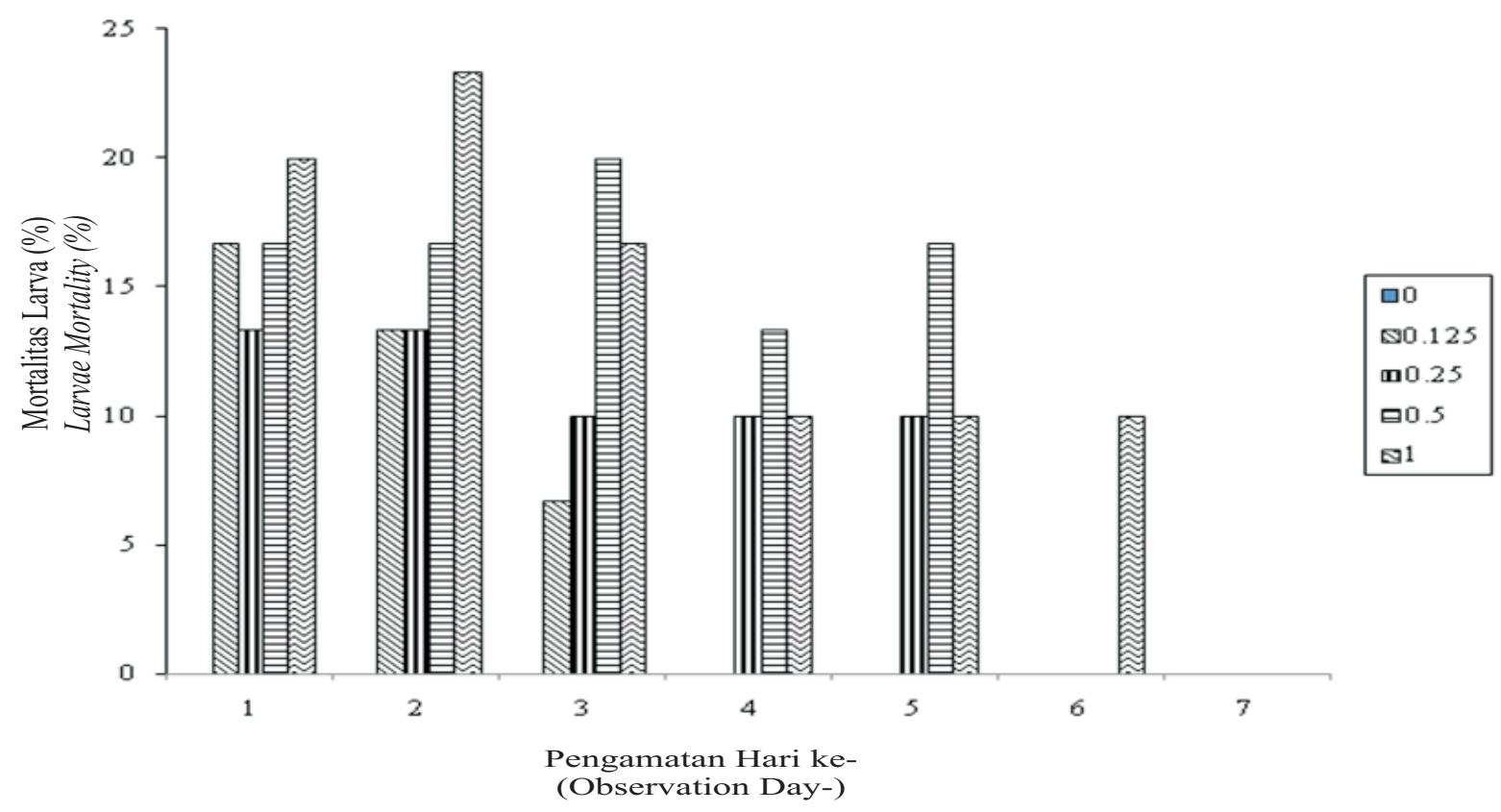

Gambar (Figure) 2. Mortalitas Eurema spp. selama tujuh hari pengamatan pada perlakuan ekstrak daging buah bintaro (Eurema spp. mortality during seven days observation on extracts treatment of bintaro's fruits)

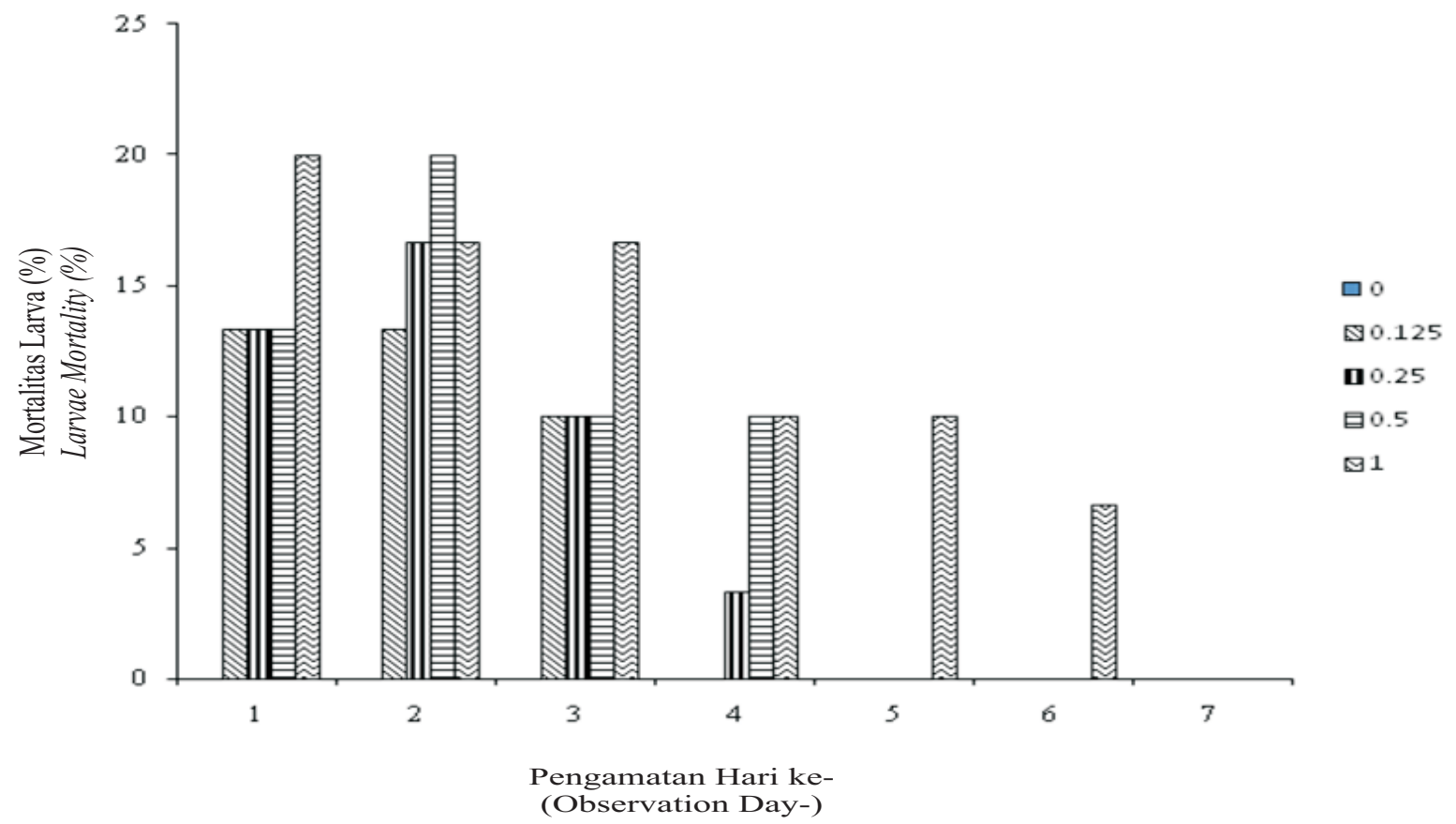

Gambar (Figure) 3. Mortalitas Eurema spp. selama tujuh hari pengamatan pada perlakuan ekstrak daun bintaro (Eurema spp. mortality during seven days obseravation on extracts treatment of bintaro's leaves) 
Tabel(Table)2. Penduga parameter toksisitas ekstrak kasar bintaro terhadap larva Eurema spp. (Parameter estimators toxicity of bintaro coarse extract againts larvae Eurema spp.)

\begin{tabular}{|l|c|c|c|c|}
\hline \multicolumn{1}{|c|}{$\begin{array}{c}\text { Ekstrak uji/ } \\
\text { Sample extracts }\end{array}$} & $a \pm \mathrm{GB}^{\mathrm{a})}$ & $b \pm \mathrm{GB}^{\mathrm{a})}$ & $\begin{array}{c}\mathrm{LC}_{50} \\
(\mathrm{SK} 95 \%)(\%)^{\mathrm{a}}\end{array}$ & $\begin{array}{c}\mathrm{LC}_{95} \\
(\mathrm{SK} 95 \%)(\%)^{\mathrm{a})}\end{array}$ \\
\hline Biji & $1,39 \pm 0,25$ & $1,92 \pm 0,41$ & 0,189 & 1,360 \\
& & $(0,115-0,257)$ & $(0,813-4,273)$ \\
Daging buah & $0,76 \pm 0,21$ & $1,52 \pm 0,37$ & 0,315 & 3,783 \\
& & & $(0,205-0,463)$ & $(1,653-34,953)$ \\
Daun & $0,65 \pm 0,20$ & $1,23 \pm 0,36$ & 0,297 & 6,453 \\
& & & $(0,161-0,476)$ & $(2,096-349,480)$ \\
\hline
\end{tabular}

${ }^{a} a=$ intersep regresi probit, $b=$ kemiringan regresi probit, $\mathrm{GB}=$ galat baku, $\mathrm{SK}=$ selang kepercayaan $(a=$ intercept of probit regression, $b=$ slope of probit regression, $G B=$ standart deviation, $S K=$ confidence interval)

\section{Pengaruh Ekstrak Bintaro terhadap Perkembangan Eurema spp.}

Ekstrak bintaro memberikan pengaruh yang signifikan terhadap perkembangan serangga Eurema spp. Larva perlakuan yang masih tersisa hidup terus diamati perkembangannya sampai menjadi pupa dan imago. Hasil penelitian menunjukkan bahwa semua jenis ekstrak bintaro memberikan pengaruh yang nyata terhadap pembentukan pupa dan imago, serta lama waktu pembentukannya sebagaimana yang disajikan pada Tabel 3, 4, 5, dan 6. Adapun pupa Eurema spp. yang terbentuk tidak berbeda dengan pupa kontrol (bentuk, ukuran dan warna) yang membedakan hanya waktu pembentukan pupa. Hasil penelitian menunjukkan hanya jenis ekstrak saja yang memberikan pengaruh yang nyata terhadap keberhasilan pembentukan pupa, konsentrasi tidak memberikan pengaruh yang nyata sebagaimana yang terlihat pada Tabel 3 .

Pada konsentrasi terendah, ekstrak biji memberikan keberhasilan pembentukan pupa paling besar yiatu sebesar $63,49 \%$, sedangkan ekstrak daging buah, dan daun berturut-turut hanya sebesar $55,56 \%$ dan $47,62 \%$. Namun pada konsentrasi tertinggi, ekstrak biji bintaro memberikan efek yang paling kuat dalam menghambat perkembangan pupa Eurema spp. Persentase keberhasilan pembentukan pupa pada ekstrak biji bintaro sebesar 16,67\%, sedangkan ekstrak daging buah dan daun masing-masing sebesar $33,33 \%$ dan $27,78 \%$.

Tabel (Table) 3. Pengaruh ekstrak bintaro terhadap keberhasilan pembentukan pupa Eurema spp. (Effects of bintaro extracts to the success of Eurema spp. pupa establishment)

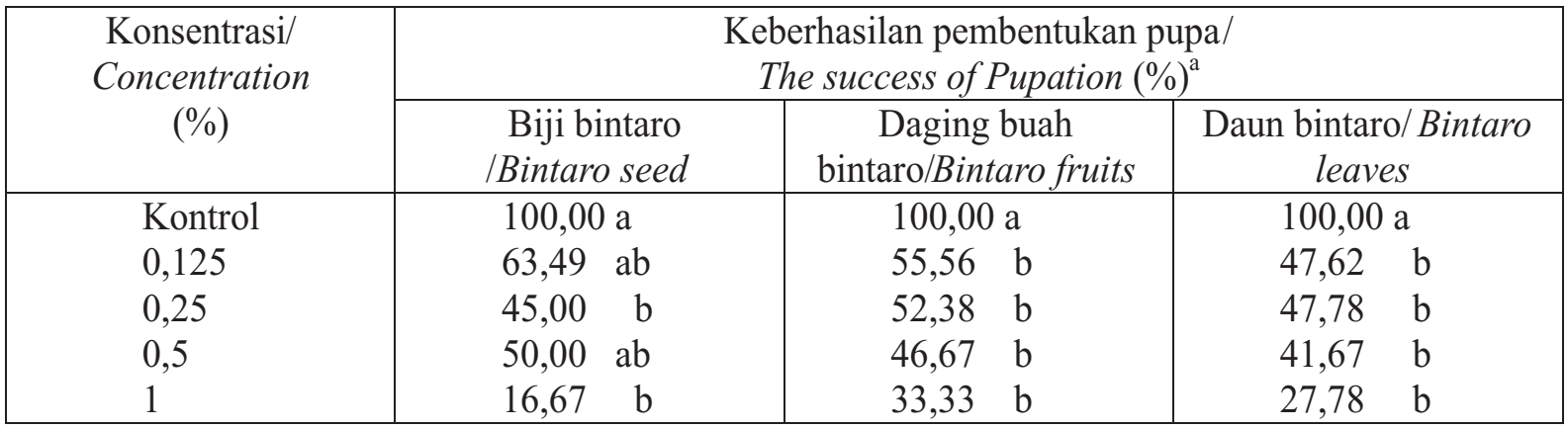

${ }^{a}$ Rataan pada kolom yang sama yang diikuti oleh huruf yang sama tidak berbeda nyata berdasarkan uji selang berganda Duncan pada taraf nyata 5\% (The average in the same column followed by the same letters is not significant based on Duncan's Multiple Range Test, $\alpha=5 \%$ ) 
Disamping mempengaruhi keberhasilan pembentukan pupa, jenis ekstrak bintaro dan konsentrasi juga memberikan pengaruh yang nyata terhadap lama waktu pembentukan pupa. Secara umum, semakin tinggi konsentrasi maka akan semakin lama waktu yang dibutuhkan untuk pembentukan pupa. Pada konsentrasi $0,125 \%$, pada ekstrak biji dan daun bintaro dibutuhkan waktu 0,3 hari lebih lama dibandingkan dengan kontrol. Pada konsentrasi
$1 \%$, ekstrak biji bintaro membutuhkan waktu 1,7 hari lebih lama dibandingkan dengan kontrol. Sedangkan pada ekstrak daging buah dan daun hanya membutuhkan waktu 1,3 hari lebih lama dibandingkan dengan kontrol. Hal ini menunjukkan bahwa ekstrak biji lebih kuat dalam menghambat pembentukan pupa, baik keberhasilan pembentukan pupa maupun lamanya waktu yang dibutuhkan.

Tabel(Table) 4. Pengaruh ekstrak bintaro terhadap waktu yang dibutuhkan untuk pembentukan pupa Eurema spp. (Effects of bintaro extracts on time required for the Eurema spp. pupa establishment)

\begin{tabular}{|c|c|c|c|}
\hline \multirow{2}{*}{$\begin{array}{c}\text { Konsentrasi/ } \\
\text { Concentration } \\
(\%)\end{array}$} & \multicolumn{3}{|c|}{$\begin{array}{l}\text { Waktu pem bentukan pupa/Pupa formation time } \\
\text { (hari/days) })^{\mathrm{a}}\end{array}$} \\
\hline & $\begin{array}{l}\text { Biji bintaro } \\
\text { /Bintaro seed }\end{array}$ & $\begin{array}{l}\text { Daging Buah } \\
\text { bintaro/Bintaro fruits }\end{array}$ & $\begin{array}{c}\text { Daun bintaro/Bintaro } \\
\text { leaves }\end{array}$ \\
\hline Kontrol & $12,0 \mathrm{a}$ & $12,0 \mathrm{a}$ & $12,0 \mathrm{a}$ \\
\hline 0,125 & $12,3 \mathrm{ab}$ & $12,0 \mathrm{a}$ & $12,3 \mathrm{ab}$ \\
\hline 0,25 & $13,0 \mathrm{bc}$ & $12,3 \mathrm{a}$ & $12,3 \mathrm{ab}$ \\
\hline 0,5 & $13,3 \quad \mathrm{c}$ & $12,7 \mathrm{ab}$ & $12,7 \mathrm{ab}$ \\
\hline 1 & 13,7 & $13,3 \quad b$ & $13,3 \mathrm{~b}$ \\
\hline
\end{tabular}

${ }^{a}$ Rataan pada kolom yang sama yang diikuti oleh huruf yang sama tidak berbeda nyata berdasarkan uji selang berganda Duncan pada taraf nyata $5 \%$ (The average in the same column followed by the same letters is not significant based on Duncan's Multiple Range Test, $\alpha=5 \%)$

Ekstrak bintaro juga memberikan pengaruh yang signifikan terhadap perkembangan pupa menjadi imago, baik dalam keberhasilan pembentukan imago maupun lamanya waktu yang dibutuhkan untuk pembentukan imago. Ekstrak biji bintaro pada konsentrasi $1 \%$ mampu menghambat pembentukan imago sehingga hanya $16,67 \%$ saja imago yang terbentuk. Sementara pada ekstrak daging buah dan daun bintaro, keberhasilan pembentukan imagonya sebesar $33,33 \%$. Hal ini menunjukkan bahwa ekstrak biji bintaro lebih kuat dalam menghambat pembentukan imago Eurema spp. dibandingkan dengan ekstrak daging buah dan daun bintaro.

Tabel(Table) 5. Pengaruh ekstrak bintaro terhadap keberhasilan pembentukan imago Eurema spp. (Effects of bintaro extracts to the success of Eurema spp. imago establishment)

\begin{tabular}{|c|c|c|c|}
\hline \multirow{2}{*}{$\begin{array}{c}\text { Konsentrasi/ } \\
\begin{array}{c}\text { Concentration } \\
(\%)\end{array}\end{array}$} & \multicolumn{3}{|c|}{$\begin{array}{c}\text { Keberhasilan Pembentukan Imago/ } \\
\text { The success of imago establishment }(\%)^{\mathrm{a}}\end{array}$} \\
\cline { 2 - 4 } & $\begin{array}{c}\text { Biji bintaro } \\
\text { Bintaro seed }\end{array}$ & $\begin{array}{c}\text { Daging buah } \\
\text { bintaro/Bintaro fruits }\end{array}$ & $\begin{array}{c}\text { Daun bintaro/ Bintaro } \\
\text { leaves }\end{array}$ \\
\hline Kontrol & $100,00 \mathrm{a}$ & $100,00 \mathrm{a}$ & $100,00 \mathrm{a}$ \\
0,125 & $41,67 \mathrm{~b}$ & $36,11 \mathrm{~b}$ & $56,56 \mathrm{a}$ \\
0,25 & $38,89 \mathrm{~b}$ & $38,89 \mathrm{~b}$ & $40,00 \mathrm{a}$ \\
0,5 & $33,33 \mathrm{~b}$ & $38,89 \mathrm{~b}$ & $33,33 \mathrm{a}$ \\
\hline
\end{tabular}

${ }^{a}$ Rataan pada kolom yang sama yang diikuti oleh huruf yang sama tidak berbeda nyata berdasarkan uji selang berganda Duncan pada taraf nyata 5\% (The average in the same column followed by the same letters is not significant based on Duncan's Multiple Range Test, $\alpha=5 \%$ ) 
Ekstrak biji dan daun bintaro memberikan pengaruh yang signifikan terhadap lamanya waktu yang dibutuhkan untuk pembentukan imago Eurema spp. (Tabel 6). Sedangkan ekstrak daging buah bintaro tidak memberikan pengaruh yang signifikan. Pada konsentrasi 0,125\% ekstrak biji bintaro memerlukan waktu 0,3 hari lebih lama daripada kontrol untuk pembentukan imago. Sementara ekstrak daging buah dan daun bintaro tidak mempengaruhi terhadap lamanya pembentukan imago. Pada konsentrasi tertinggi, ekstrak biji bintaro memerlukan 1,7 hari lebih lama dibandingkan dengan kontrol. Sedangkan ekstrak daging buah dan bintaro hanya memerlukan waktu 0,7 hari dan 1 hari lebih lama menjadi imago. Hal ini menunjukkan bahwa ekstrak biji bintaro lebih kuat menghambat pembentukan imago Eurema spp.

Tabel(Table) 6. Pengaruh ekstrak bintaro terhadap waktu yang dibutuhkan untuk pembentukan imago Eurema spp. (Effects of bintaro extracts on establishment time of imago)

\begin{tabular}{|l|c|c|c|}
\hline \multirow{2}{*}{$\begin{array}{c}\text { Konsentrasi/ } \\
\begin{array}{c}\text { Concentrate } \\
(\%)\end{array}\end{array}$} & \multicolumn{3}{|c|}{$\begin{array}{c}\text { Waktu pembentukan imago/ } \\
\text { Establisment Time of Imago (hari/days) }\end{array}$} \\
\cline { 2 - 4 } & $\begin{array}{c}\text { Biji bintaro } \\
\text { /Bintaro seed }\end{array}$ & $\begin{array}{c}\text { Daging buah } \\
\text { bintaro/ Bintaro fruits }\end{array}$ & $\begin{array}{c}\text { Daun bintaro/Bintaro } \\
\text { leaves }\end{array}$ \\
\hline Kontrol & $6,0 \mathrm{a}$ & $6,0 \mathrm{a}$ & $6,0 \mathrm{a}$ \\
0,125 & $6,3 \mathrm{a}$ & $6,0 \mathrm{a}$ & $6,0 \mathrm{a}$ \\
0,25 & $6,3 \mathrm{a}$ & $6,0 \mathrm{a}$ & $6,7 \mathrm{ab}$ \\
0,5 & $7,0 \mathrm{ab}$ & $6,3 \mathrm{a}$ & $6,7 \mathrm{ab}$ \\
1 & $7,7 \mathrm{~b}$ & $6,7 \mathrm{a}$ & $7,0 \mathrm{~b}$ \\
\hline
\end{tabular}

${ }^{a}$ Rataan pada kolom yang sama yang diikuti oleh huruf yang sama tidak berbeda nyata berdasarkan uji selang berganda Duncan pada taraf nyata $5 \%$ (The average in the same column followed by the same letters is not significant based on Duncan's Multiple Range Test, $\alpha=5 \%$ )

\section{B. Pembahasan}

Tiga jenis ekstrak bintaro, yaitu ekstrak biji, daging buah, dan daun bintaro memberikan pengaruh yang signifikan terhadap mortalitas larva dan penghambatan perkembangan serangga Eurema spp. Pada suatu tanaman terdapat senyawa metabolit primer dan metabolit sekunder. Senyawa metabolit sekunder yang terkandung di dalam bintaro diduga memberikan efek insektisidal terhadap serangga hama Eurema spp. Senyawa metabolit sekunder adalah senyawa kimia tumbuhan yang tidak secara universal ditemukan pada semua tumbuhan tingkat tinggi, tetapi terbatas hanya pada taksa tumbuhan tertentu, atau terdapat pada taksa tumbuhan tertentu dalam konsentrasi lebih tinggi dari yang lain serta tidak ada hubungan yang nyata berkaitan dengan peranannya sebagai nutrisi untuk serangga (Schoonhoven et al., 1998). Senyawa metabolit sekunder juga tidak terlalu berperan penting dalam proses pertumbuhan dan perkembangan tumbuhan, namun demikian terdapat variasi dan jumlah metabolit sekunder tumbuhan yang sangat besar
(Dadang \& Prijono, 2008). Contoh senyawa metabolit sekunder yaitu flavonoid, terpenoid dan alkaloid yang mana senyawa-senyawa ini dapat melindungi tanaman dari serangan hama dan penyakit (Dadang \& Prijono, 2008).

Salleh (1997) melaporkan bahwa pada daun, buah dan kulit batang bintaro mengandung saponin, daun dan buahnya mengandung polifenol, disamping itu kulit batangnya mengandung tanin. Selain itu PROSEA (2002) melaporkan bahwa biji bintaro mengandung cerberin yang bersifat toksik terhadap tikus.

Saponin merupakan senyawa yang bersifat toksik (Dadang \& Prijono, 2008). Sedangkan fenolik mempunyai banyak peranan pada tumbuhan seperti flavonoid sebagai pengatur pertumbuhan berbagai tumbuhan, asam fenolik dan tanin berperan sebagai pelindung tanaman dari patogen (Dadang \& Prijono, 2008). Beberapa senyawa fenol berfungsi sebagai penolak makan serangga namun bisa juga berperan sebagai penstimuli makan pada serangga lain. Dapat pula serangga yang memakan akan mendapatkan pengaruh buruk namun bagi spesies lain akan mendapatkan manfaat. 
Aktivitas kematian yang paling tinggi yang terjadi pada perlakuan ekstrak biji diduga disebabkan karena kandungan cerberin yang terdapat di dalam biji. Cerberin merupakan golongan alkaloid/glikosida yang diduga berperan terhadap mortalitas serangga uji. Tomlinson (1986) melaporkan bahwa cerberin dapat menganggu fungsi saluran ion kalsium di dalam otot jantung, sehingga menganggu detak jantung dan dapat menyebabkan kematian. Selain adanya cerberin diduga kandungan minyak yang banyak pada bagian biji mengakibatkan spirakel larva Eurema spp. tersumbat karena minyak biji bintaro menempel pada tubuh larva. Tersumbatnya spirake mengakibatkan larva mengalami kematian secara perlahan. Sedangkan daging buah dan daunnya mengandung saponin dan polifenol yang dikenal sangat toksik terhadap serangga dan bisa menghambat aktivitas makan serangga. Senyawa-senyawa yang terkandung dalam bagian tanaman bintaro tersebut yang diduga kuat memberikan efek yang signifikan terhadap mortalitas larva Eurema spp.

Disamping menyebabkan mortalitas, ekstrak bintaro juga memberikan efek yang signifikan terhadap penghambatan pertumbuhan serangga hama dalam hal ini keberhasilan pembentukan pupa dan imago, serta lamanya waktu yang dibutuhkan untuk pembentukan pupa dan imago Eurema spp. Dadang \& Prijono (2008) melaporkan bahwa pertumbuhan dan perkembangan serangga dipengaruhi oleh kualitas dan kuantitas makanan yang dikonsumsi. Serangga-serangga yang mengkonsumsi sumber makanan yang cocok/sesuai akan tumbuh dan berkembang secara baik. Sebaliknya serangga yang mengkonsumsi sumber makanan yang miskin zat-zat nutrisi yang diperlukan akan mengalami penghambatan dalam pertumbuhan dan perkembangannya. Demikian juga seranggaserangga yang dalam makanannya terdapat senyawa-senyawa kimia tertentu akan terhambat pertumbuhan dan perkembangannya. Senyawasenyawa semacam itu terdapat di dalam tanaman (Dadang \& Prijono, 2008).

Diduga senyawa kimia yang terdapat di dalam ekstrak bintaro mengandung senyawasenyawa yang mempunyai efek penghambat perkembangan serangga. Pada ekstrak biji bintaro mempunyai efek yang lebih kuat dibandingkan dua jenis ekstrak lainnya, hal ini kemungkinan disebabkan karena kandungan bahan aktif yang mempunyai efek menghambat perkembangan serangga lebih banyak terdapat di dalam biji bintaro. Sedangkan kurang kuatnya efek terhadap perkembangan serangga dari bagian daging buah dan daun bintaro kemungkinan disebabkan karena kadar senyawa aktif yang terdapat pada bagian tersebut lebih rendah.

Adanya efek penghambatan perkembangan serangga hama yang terdapat pada ekstrak bintaro menunjukkan bahwa bintaro bisa dimanfaatkan secara efektif untuk mengendalikan hama Eurema spp., karena bintaro mempunyai efek mematikan sekaligus menghambat perkembangan hama. Hal ini berarti bahwa apabila ditemukan larva serangga hama yang masih hidup maka akan kecil peluangnya untuk melanjutkan siklus hidupnya.

Pemanfaatan ekstrak bintaro dalam mengendalikan serangga hama Eurema spp. dapat dilakukan dengan menggunakan semua bagian tanaman bintaro, baik biji, daging buah, dan daunnya, karena ketiga bagian tersebut mempunyai efek insektisidal terhadap Eurema spp. Biomassa yang digunakan untuk tiap-tiap bagian tanaman bintaro berbeda karena mempunyai kekuatan insektisidal yang berbeda. Dalam pemanfaatan tanaman yang mempunyai potensi sebagai insektisida nabati, terdapat beberapa hal yang perlu diperhatikan yaitu : 1) Tanaman yang berpotensi sebagai insektisida nabati mudah diperoleh di alam dan terdapat dimana-mana, 2) Biomassanya bisa diperoleh dalam keadaan berlimpah, 3) Mudah terurai di alam sehingga tidak mencemari lingkungan serta relatif aman bagi manusia dan hewan peliharaan karena residunya mudah hilang. Oleh karena itu bagian daun bisa saja dimanfaatkan sebagai pengendali hama mengingat daun bisa didapatkan dalam keadaan berlimpah dibandingkan dengan buahnya, hanya saja biomassa yang dibutuhkan harus lebih banyak agar supaya lebih efektif dimanfaatkan dalam pengendalian hama Eurema spp.

\section{KESIMPULAN DAN SARAN}

\section{A. Kesimpulan}

Ekstrak bintaro (Cerbera odollam Gaertn.) memberikan pengaruh yang signifikan terhadap mortalitas dan penghambatan perkembangan serangga hama Eurema spp. Mortalitas larva Eurema spp. paling tinggi terjadi pada perlakuan ekstrak biji bintaro yaitu sebesar 90\%, selanjutnya daging buah dan daun bintaro 
berturut-turut sebesar $83,33 \%$ dan $80 \%$. Ekstrak biji bintaro juga paling kuat dalam menghambat perkembangan serangga hama, dimana persentase pembentukan pupa dan imago hanya sebesar $16,67 \%$ dengan waktu yang dibutuhkan untuk menjadi pupa dan imago masing-masing 1,7 hari lebih lama dibandingkan dengan kontrol. Dengan demikian senyawa yang terkandung di dalam bagian bintaro memberikan efek insektisidal terhadap serangga hama Eurema spp.

\section{B. Saran}

Perlu dilakukan penelitian lebih lanjut mengenai keefektifan dan keefisienan pemanfatan ekstrak bintaro dalam mengendalikan serangga hama Eurema spp. pada skala lapangan.

\section{DAFTAR PUSTAKA}

Dadang, D. Prijono. 2008. Insektisida Nabati : Prinsip, Pemanfaatan dan Pengembangan. Departemen Proteksi Tanaman. Fakultas Pertanian. IPB. Bogor.

Heyne, K. 1987. Tumbuhan Berguna Indonesia Jilid III. Badan Litbang Kehutanan Jakarta. Penerjemah. Yayasan Sarana Wana Jaya. Jakarta.

Prijono, D. 1998. Insectisidal activity of Meliaceous seed extracts against
Crocidolomia binotalis Zeller (Lepidoptera : Pyralidae). Bul HPT 10: 1-7.

PROSEA. 2002. Plant Resources of South-East Asia 12 : Medicinal and Poisonous Plants 2. PROSEA. Bogor. Indonesia.

Salleh. 1997. Ethno botany, Ethno Pharmacognasy and Documentation of Malaysia Medicinal and Aromatic Plants. UKM. Malaysia. http: //www. borneofocus.com/saip/vaic/R\&D/article5. htm.

SAS Institute. 1990. SAS/STAT User's Guide, Version 6, Vol. 2. Eth ed. Cary (NC) : SAS Institute.

Schoonhoven, LM., T. Jermy, JJA. Van Loon. 1998. Insect Plant Biology : from Physiology to Evolution. Chapman \& Hall. London. 409p.

Suharti, M. 1991. Buku Pintar Sengon Paraserianthes falcataria (L.) NIELSEN. Departemen Kehutanan. Bogor.

Tarmadi, D., AH. Prianto, I. Guswenrivo, T. Kartika, S. Yusuf. 2007. Pengaruh Ekstrak Bintaro (Cerbera odollam Gaertn.) dan Kecubung (Brugmansia candida Pers) terhadap Rayap Tanah Captotermes sp. J. Trop. Wood Scie. \& Tech. Vol 5 No 12007.

Tomlinson, CB. 1986. The Botany of Mangroves. Cambridge University Press. Cambridge. 